\title{
Back-Diffusion of $\mathrm{CO}_{2}$ and Its Influence on the Intramural pH in Gastric Mucosa
}

\author{
R. G. Fiddian-Green, M.D., ${ }^{1}$ G. PitTenger, B.S., \\ AND W. M. Whitehouse, JR., M.D. \\ Department of Surgery, University of Michigan Medical Center, Ann Arbor, Michigan 48109
}

Presented at the Annual Meeting of the Association for Academic Surgery, Chicago, Illinois, November 9-11, 1981

\begin{abstract}
We have examined the back-diffusion of $\mathrm{CO}_{2}$ generated by buffering $\mathrm{HCl}$ with $\mathrm{NaHCO}_{3}$ in the stomach, observed its influence on the $\mathrm{pH}$ in the wall of the gastric mucosa, and compared its effects with those of $\mathrm{HCl}$. Isolated stomachs of 17 anesthetized dogs were exposed to either (1) $250 \mathrm{ml} \mathrm{NaCl}$ at $\mathrm{pH} 7$, or (2) $125 \mathrm{ml} \mathrm{HCl}(12.5 \mathrm{meq})+125 \mathrm{ml} \mathrm{NaHCO}(12.5 \mathrm{meq})$ to gencrate $12.5 \mathrm{meq} \mathrm{CO}_{2}$ in the stomach, or (3) $250 \mathrm{ml} \mathrm{HCl}$ alone to give either 12.5 or $35 \mathrm{meq} \mathrm{HCl}$ in the stomach. Samples of gastric fluid and arterial blood were collected every $20 \mathrm{~min}$ for $6 \mathrm{hr}$ and analyzed for $\mathrm{pH}$ and $p \mathrm{CO}_{2}$. The intramural $\mathrm{pH}$ of the gastric wall was measured by hollow viscus tonometry. The $p \mathrm{CO}_{2}$ in gastric juice rose to $1184 \pm 139 \mathrm{~mm} \mathrm{Hg}$ upon the generation of $\mathrm{CO}_{2}$ in the stomach. The $t_{1 / 2}$ of the $\mathrm{CO}_{2}$ generated by the buffering of acid was $32 \pm 4 \mathrm{~min}$ and of the $p \mathrm{CO}_{2}$ was $18.7 \pm 0.7 \mathrm{~min}$. The $t_{1 / 2}$ of an equimolar amount of $\mathrm{HCl}$ was $2 \mathrm{hr} 42 \mathrm{~min} \pm 40 \mathrm{~min}$. The disappearance of the $\mathrm{CO}_{2}$ was accompanied by a rise in intragastric pH from $6.0 \pm 0.01$ to $6.8 \pm 0.09(P<0.05)$, and by a fall in intramural $\mathrm{pH}$ in the gastric wall from control values of $7.31 \pm 0.05$ to $6.3 \pm 0.8(P<0.001)$. In contrast the $\mathrm{pH}$ in gastric fluid did not change and the $\mathrm{pH}$ in the intramural fluid did not fall below control values following the administration of 12.5 or $35 \mathrm{meq} \mathrm{HCl}$ alone.
\end{abstract}

\section{INTRODUCTION}

Upon contact with bicarbonate secretions in the duodenum, gastric acid is buffered by being transformed from a strong acid $(\mathrm{HCl})$ into a weaker acid $\left(\mathrm{H}_{2} \mathrm{CO}_{3}\right)$ with a $\mathrm{p} K_{a}$ of 6.1. The dissociation of this weak acid yields $\mathrm{CO}_{2}$ and induces a rise in $p \mathrm{CO}_{2}$ in the luminal fluid that has been observed to be as high as $800 \mathrm{~mm} \mathrm{Hg}[24,29]$. Neutralization of the acid is achieved by the disposal of the $\mathrm{CO}_{2}$. Isotopic studies using ${ }^{14} \mathrm{C}$-labeled bicarbonate have shown that $95 \%$ of the $\mathrm{CO}_{2}$ formed by the buffering of gastric acid is disposed by the lungs [27]. Thus the disposal of gastric acid in the duodenum is, in effect, achieved by the conversion of acid present in one form $\left(\mathrm{H}^{+}\right)$to acid present in another form $\left(\mathrm{CO}_{2}\right)$ that can be exhaled from the lungs.

\footnotetext{
${ }^{1}$ To whom correspondence should be addressed: Department of Surgery, University Hospital, Box 46, SAC Building, Ann Arbor, Mich. 48109.
}

Although in healthy subjects buffering of gastric acid by bicarbonate occurs in the duodenum, in some patients, such as those with gastric ulcers, buffering of acid by bicarbonate secretions may occur in the stomach $[2,8,21]$. In this study we have examined the possibility that the buffering of acid by bicarbonate in the stomach might increase the gastric mucosal permeability to acid by transforming acid present in a relatively impermeable form $\left(\mathrm{H}^{+}\right)$to acid present in a more permeable form $\left(\mathrm{CO}_{2}\right)$.

\section{METHODS}

\section{Experimental Model}

After an 18-hr fast 22 adult mongrel dogs weighing between 12 and $20 \mathrm{~kg}$ were anesthetized with pentobarbital. Their stomachs were isolated by ligatures placed around the pylorus and esophagus. A polyethylene catheter for the intermittent sampling of luminal fluid was placed into the stomach and se- 
cured with two purse string sutures. The stomach was irrigated clear with saline and emptied. A second catheter, with heparin lock, was placed into the femoral artery for the intermittent sampling of blood. The stomach was filled with $250 \mathrm{ml}$ of normal saline and the abdomen closed with towel clips allowing only the polyethylene tube to transverse the abdominal wound. Samples of luminal fluid and arterial blood were collected anaerobically at 20-min intervals thereafter and placed onto ice. Care was taken to discard any fluid contained in the dead space. After 1 hr the gastric contents were aspirated completely and replaced with $250 \mathrm{ml}$ of test fluid (see below). Further samples were collected at 20-min intervals thereafter for another $4 \mathrm{hr}$. After the last sample had been collected the volume of fluid remaining in the stomach was aspirated completely and measured. Previous studies have shown that the fractional loss of fluid collected by aspiration alone with an open pylorus decreases linearly as the volume of fluid aspirated increased, and to be negligible when the volume of fluid aspirated exceed $100 \mathrm{ml}$ [10]. The fractional loss has also been shown to be negligible when fluid was prevented from leaving the stomach [19]. No inert marker was, therefore, used to aid in the measurement of the large volume $( \pm 200 \mathrm{ml})$ of fluid remaining in the stomach at the end of these experiments in which gastric emptying was prevented by pyloric ligature.

\section{Experimental Protocols}

1. Controls. Five dogs were used as controls, In these dogs the test fluid placed into the stomach consisted of $250 \mathrm{ml}$ normal saline.

2. Back-diffusion of $\mathrm{H}^{+}$. Seven dogs were used to determine the rate at which $\mathrm{H}^{+}$diffused from the stomach. In the first four dogs the test fluid consisted of $12.5 \mathrm{meq} \mathrm{HCl}$ diluted in normal saline to a final volume of $250 \mathrm{ml}$ to give an in vitro concentration of $50 \mathrm{meq} /$ liter. In the remaining three dogs the test fluid consisted of $35 \mathrm{meq} \mathrm{HCl}$ diluted in normal saline to a final volume of $250 \mathrm{ml}$ to give an in vitro concentration of $140 \mathrm{meq} /$ liter.

3. Back-diffusion of $\mathrm{CO}_{2}$. Five other dogs were used to determine the rate at which $\mathrm{CO}_{2}$ diffused from the stomach. In each of these dogs $12.5 \mathrm{meq} \mathrm{HCl}$ and $12.5 \mathrm{meq}$ $\mathrm{NaHCO}_{3}$ were introduced simultaneously into the stomach to give a final volume of $250 \mathrm{ml}$ and to generate $12.5 \mathrm{meq} \mathrm{CO}_{2}$ in the stomach and a maximum in vitro $\mathrm{CO}_{2}$ concentration of $50 \mathrm{meq} / \mathrm{liter}$ in an acidic environment.

4. Diffusion of $\mathrm{CO}_{2}$ in stomach vs duodenum. The permeability of gastric mucosa to $\mathrm{CO}_{2}$ was compared with permeability of duodenal mucosa in another five dogs. In these dogs the stomach and duodenum were separately isolated by ligatures placed around the esophagus, pylorus, and distal duodenum. Pancreatic and biliary secretion was not interrupted. Both gastric and duodenal pouches were canulated. The gastric pouch was filled with $200 \mathrm{ml}$ normal saline and the duodenal pouch with $50 \mathrm{ml}$ normal saline. Samples of fluid were collected at $20-\mathrm{min}$ intervals for $1 \mathrm{hr}$ and more frequently for the next $90 \mathrm{~min}$. The volume of fluid aspirated was replaced with an equal volume of saline. After the first hour the dogs were made to rebreathe into a bag containing $100 \% \mathrm{O}_{2}$ for $30 \mathrm{~min}$ to raise the $p \mathrm{CO}_{2}$ in the arterial blood. The dogs were allowed to breathe spontaneously again for the last hour.

\section{Measurement of $\mathrm{pH}$ and $p \mathrm{CO}_{2}$}

The $\mathrm{pH}$ and $p \mathrm{CO}_{2}$ in samples of arterial blood and the $p \mathrm{CO}_{2}$ in samples of luminal fluid were measured with a $\mathrm{pH} /$ blood-gas analyzer (IL Micro 13 Instrumentation Laboratory, Lexington, Mass.). The $\mathrm{pH}$ in luminal fluid was measured with a separate $\mathrm{pH}$ electrode (Radiometer, Copenhagen). The calibration of the instruments was checked at the beginning and end of each experiment. The acidity $\left[\mathrm{H}^{+}\right]$in samples of luminal fluid was determined from the measurements of $\mathrm{pH}$ in the manner described by 
Moore and Scarlata [19]. The correction factor applicable to our experiments for conversion of hydrogen ion activity $\left[\mathrm{H}_{\mathrm{a}}^{+}\right]$to hydrogen ion concentration $\left[\mathrm{H}_{\mathrm{c}}^{+}\right]$was derived by adding known amounts of $\mathrm{HCl}$ to normal saline that had been incubated in a volume of $250 \mathrm{ml}$ in the stomach (Fig. 1).

\section{Measurement of Intramural pH}

The $\mathrm{pH}$ in the wall of the stomach was measured by hollow viscus tonometry [1]. The intramural $\mathrm{pH}$ was calculated from the $p \mathrm{CO}_{2}$ in luminal fluid and the bicarbonate concentration in arterial blood with the Henderson-Hasselbach equation. This method of measuring intramural $\mathrm{pH}\left(\mathrm{pH}_{\mathrm{I}}\right)$ depends upon the assumption that $\mathrm{CO}_{2}$ is freely diffusible in the cell membrane, and that the $p \mathrm{CO}_{2}$ in the luminal fluid equilibrates with that in the wall of the gut. It depends also upon the knowledge that the $p \mathrm{CO}_{2}$ within cells is linearly related to the $p \mathrm{CO}_{2}$, in their extracellular environment [23]. It is also dependent upon the assumption that the bicarbonate concentration in the wall of the gut is the same as that being delivered to the gut in arterial blood. Using this method the $\mathrm{pH}_{1}$ in the wall of the stomach was found to be $7.47 \pm 0.03$ in 16 dogs and in the duodenum to be $7.33 \pm 0.03$ in 10 dogs when

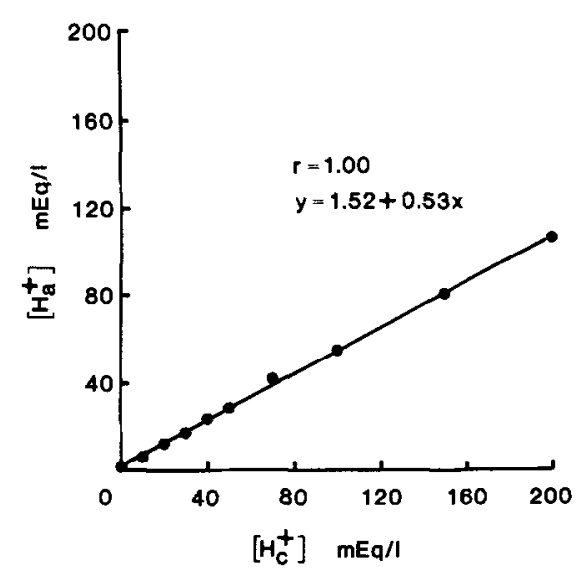

FIG. 1. Comparison between hydrogen ion activity $\left[\mathrm{H}_{\mathrm{a}}^{+}\right]$, calculated from the measured $\mathrm{pH}$, and the hydrogen ion concentration $\left[\mathrm{H}_{\mathrm{c}}^{+}\right]$induced by adding known amounts of $\mathrm{HCl}$ to $250 \mathrm{ml}$ of normal saline that have been incubated in an isolated canine stomach.

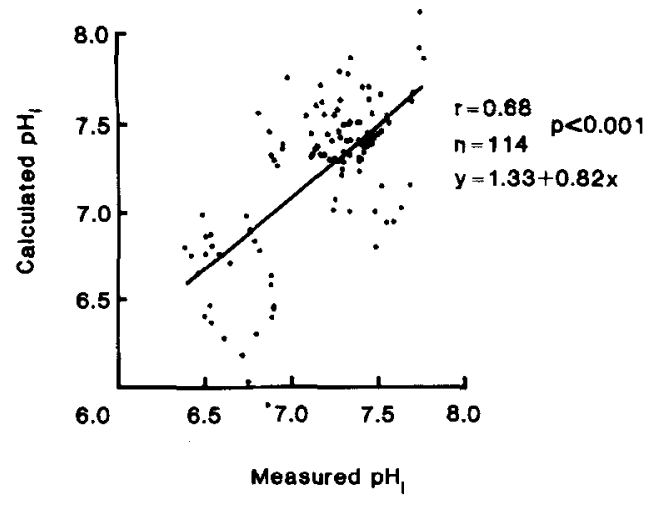

FIG. 2. Comparison between intramural $\mathrm{pH}\left(\mathrm{pH}_{\mathrm{l}}\right)$ in submucosal space, measured directly with a micro-pH probe, and that calculated from the $\mathrm{pCO}_{2}$ in luminal fluid and $\left[\mathrm{HCO}_{3}^{-}\right]$in arterial blood. Similar relationships existed in the stomach $(n=40, r=0.76)$, small bowel $(r=0.65)$, and colon $(r=0.91)$.

measured $1 \mathrm{hr}$ after allowing the $p \mathrm{CO}_{2}$ in luminal fluid to equilibrate with that in the wall of the gut. The validity of calculating the intramural $\mathrm{pH}$ in this manner was established by direct measurement with a micro-glass $\mathrm{pH}$ probe (Microelectrodes Ind., Londonderry, N. H.) placed in a submucosal tunnel in preliminary studies incorporating 114 paired readings in the stomach, small bowel, and colon of 16 dogs. The validity of calculating the intramural $\mathrm{pH}$ in this manner was determined in a variety of conditions, including intestinal ischemia and the presence of exogenous acid in the stomach. No attempt was made to maintain the $\mathrm{pH}$ in the lumen at any fixed level during these validation experiments (Fig. 2).

\section{Statistics}

The data were expressed as a mean \pm standard error of the mean and statistical significance assessed by $t$ tests.

\section{RESULTS}

\section{Controls}

The $\mathrm{pH}$ in the lumen of the stomach remained constant for the duration of each control experiment (Fig. 3), as did the $\mathrm{CCO}_{2}$ (Fig. 4). The $p \mathrm{CO}_{2}$ in luminal fluid equilibrated over a period of $1 \mathrm{hr}$ with that in 


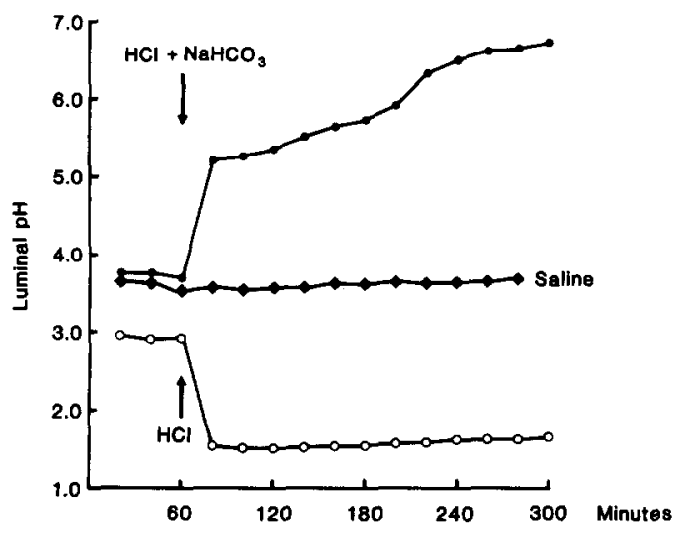

Fig. 3. Mean intraluminal pH measured in the stomach during exposure to $250 \mathrm{ml}$ normal saline $(n=5)$, and to $12.5 \mathrm{meq} \mathrm{HCl}(n=4)$ and $12.5 \mathrm{meq} \mathrm{HCl}$ plus $12.5 \mathrm{meq} \mathrm{NaHCO}_{3}(n=5)$ each diluted in $250 \mathrm{ml}$ saline.

arterial blood (Fig. 5). The volume of fluid added to the stomach at the beginning of each experiment $(250 \mathrm{ml})$ fell by $60 \pm 2 \mathrm{ml}$ due to the intermittent sampling of fluid and to the diffusion of fluid from the stomach. The volume of fluid present in the stomach when each sample was collected was calculated in the knowledge that the volume of fluid removed with each sample and the volume of fluid lost by diffusion [3] was the same in each 20 -min test period. The rate of acid secretion within each 20 -min period, calculated on the basis of these volumes and $\left[\mathrm{H}_{\mathrm{c}}^{+}\right]$, remained very low for the duration of each of these control experiments. The $\mathrm{pH}$ in the wall of the stomach, measured by hollow viscus tonometry, fell slightly during the course of the control experiments (Fig. 6).

\section{Back-Diffusion of $\mathrm{H}^{+}$}

The $\mathrm{pH}$ in the stomach fell following the addition of $\mathrm{HCl}$ and remained fairly constant thereafter (Fig. 3). The $p \mathrm{CO}_{2}$ did not change from control values (Fig. 4). The volume of fluid $(250 \mathrm{ml})$ added to the stomach at the beginning of each experiment fell by $62 \pm 2.4 \mathrm{ml}$ during the $4 \mathrm{hr}$ experiments due to the intermittent sampling of fluid and also to the diffusion of acid from the stomach. The amount of acid present in the stom- ach at the beginning of each experiment $(12.87 \pm 1.0 \mathrm{meq})$ decreased with the passage of time. The $t_{1 / 2}$ of this $\mathrm{H}^{+}$was $2 \mathrm{hr}$ and $42 \pm 40 \mathrm{~min}$ (Table 1). The rate at which $\mathrm{H}^{+}$left the stomach during each 20 min test period was linearly related to the average of the $\left[\mathrm{H}_{\mathrm{c}}^{+}\right]$gradients present at the beginning and end of each test period (Fig. 7). The positive intercept of this regression equation $(0.18 \mathrm{meq} / \mathrm{hr})$ was a reflection of the basal rate of acid secretion, and was of the same order as the basal rate of acid secretion observed in the same dogs during the first hour of each experiment $(0.01 \pm 0.08$ $\mathrm{meq} / \mathrm{hr}$ ). The slope of this regression equation (0.048) provided a measure of the gastric mucosal permeability to $\mathrm{H}^{+}$in the seven dogs studied.

\section{Back-Diffusion of $\mathrm{CO}_{2}$}

The $\mathrm{pH}$ in the lumen of the stomach rose rapidly toward neutrality following the introduction of $\mathrm{HCl}$ and $\mathrm{NaHCO}_{3}$ into the stomach (Fig. 3). At the same time the $p \mathrm{CO}_{2}$ in the lumen of the stomach rose to unre-

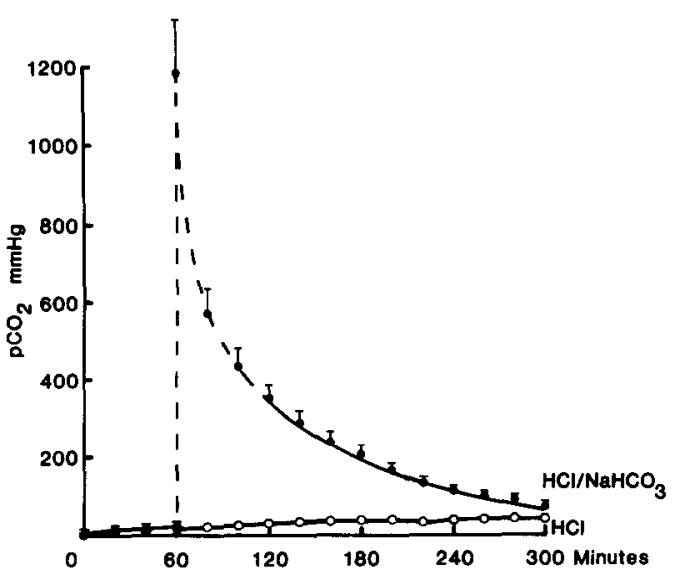

FIG. 4. Intraluminal $p \mathrm{CO}_{2}$ in the stomach measured during exposure to $250 \mathrm{ml}$ normal saline $(n=5)$, and to $12.5 \mathrm{meq} \mathrm{HCl}(n=4)$ and $12.5 \mathrm{meq} \mathrm{NCl}$ plus 12.5 meq $\mathrm{NaHCO}_{3}(n=5)$ each diluted in $250 \mathrm{ml}$ saline. Values obtained during exposure to saline and $\mathrm{HCl}$ were identical. Values obtained during the initial exposure to $\mathrm{HCl}$ and $\mathrm{NaHCO}_{3}$ were too high to measure directly. Values above $280 \mathrm{~mm} \mathrm{Hg}$ were extrapolated from the regression equations in Table 2 . 


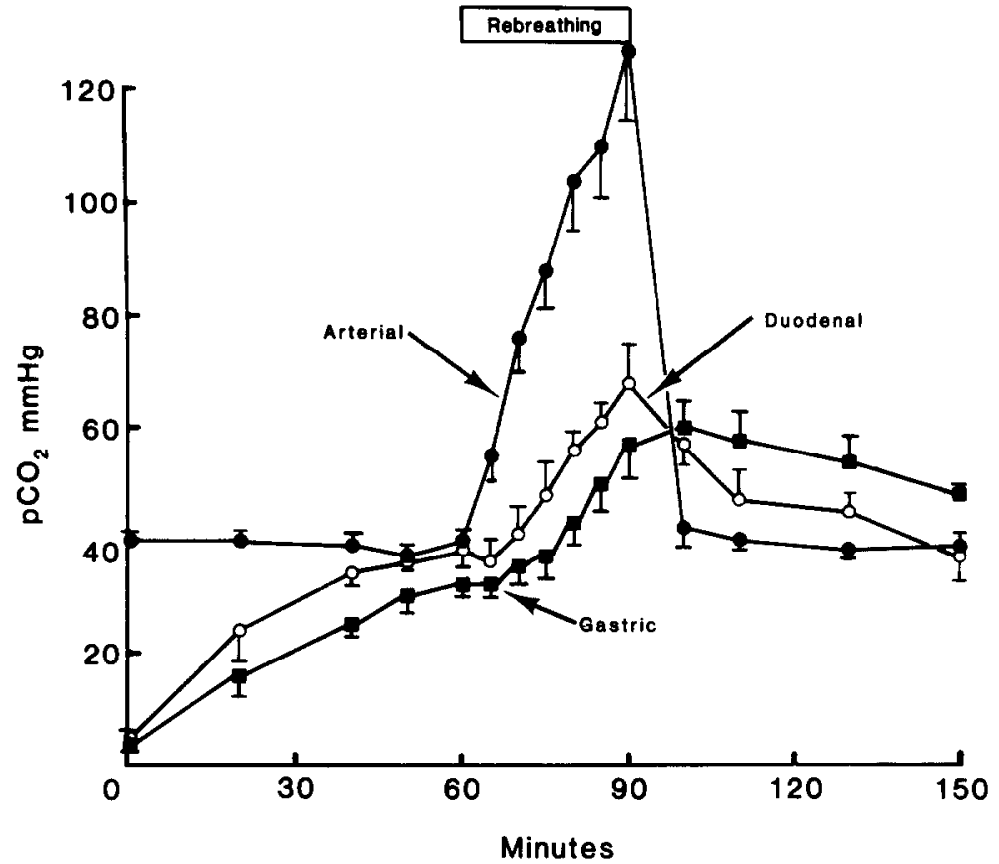

FIG. 5. Influence of rebreathing into a bag containing $100 \% \mathrm{O}_{2}$ on $p \mathrm{CO}_{2}$ in arterial blood, duodenal fluid, and gastric fluid in five anesthetized dogs.

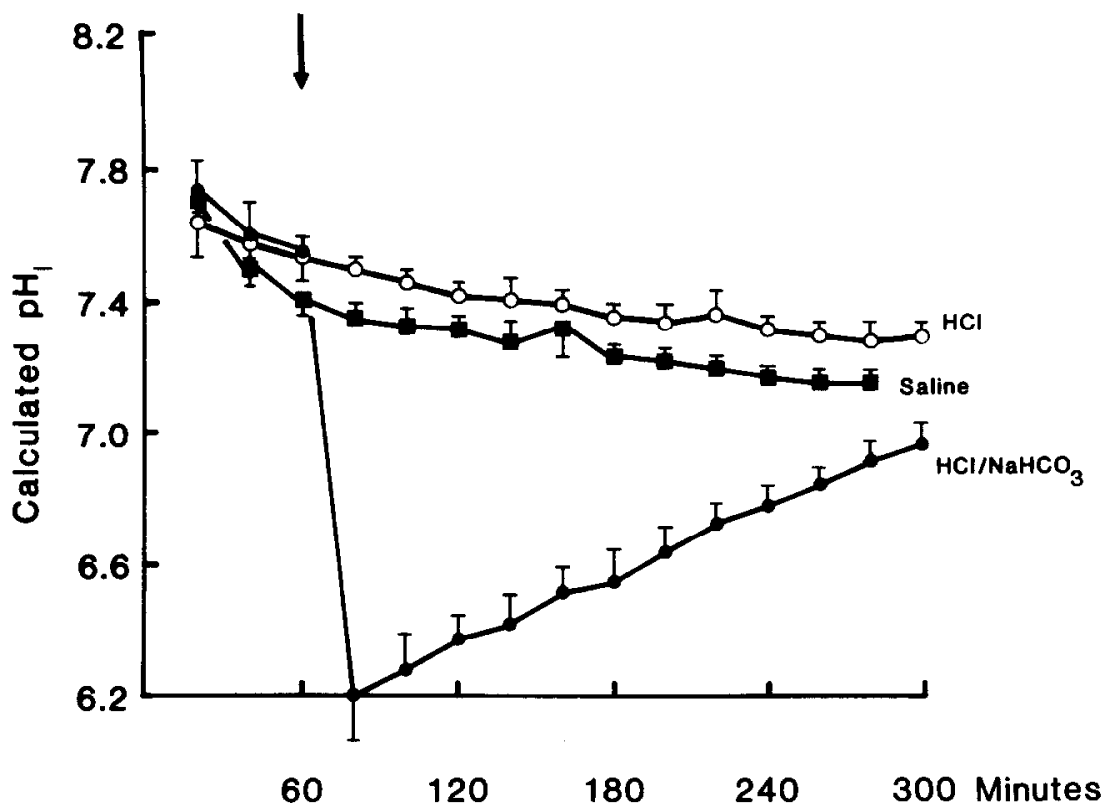

FiG. 6. Intramural pH, calculated from $p \mathrm{CO}_{2}$ in gastric fluid and [ $\left.\mathrm{HCO}_{3}^{-}\right]$in arterial blood, during luminal exposure to $250 \mathrm{ml}$ saline $(n=5)$, and to either $12.5 \mathrm{meq}$ or $35 \mathrm{meq} \mathrm{HCl}(n=7)$ and $12.5 \mathrm{meq}$ $\mathrm{HCl}$ plus $12.5 \mathrm{meq} \mathrm{NaHCO}_{3}(n=5)$ each diluted in $250 \mathrm{ml}$ of normal saline. Values obtained during exposure to $\mathrm{HCl}$ and $\mathrm{NaHCO}_{3}$ werc significantly lower than those obtained during exposure to either saline or $\mathrm{HCl}(P<0.001)$. 
TABLE 1

$\mathrm{H}^{+}$LOG REGRESSION EQUATIONS ${ }^{a}$

\begin{tabular}{cccc}
\hline$r$ & $a$ & $b$ & \multicolumn{1}{c}{$t_{1 / 2}$} \\
\hline 0.71 & 15.83 & -1.53 & $2 \mathrm{hr} 56 \mathrm{~min}$ \\
0.95 & 11.56 & -1.31 & $1 \mathrm{hr} 23 \mathrm{~min}$ \\
0.73 & 11.99 & -1.07 & $4 \mathrm{hr} 27 \mathrm{~min}$ \\
0.87 & 17.08 & -1.26 & $2 \mathrm{hr} 2 \mathrm{~min}$ \\
$\bar{x} \pm$ SEM & $12.87 \pm 1.0$ & & $2 \mathrm{hr} 42 \mathrm{~min} \pm 40 \mathrm{~min}$ \\
\hline
\end{tabular}

a The $\mathrm{H}^{+} \log$ regression equations observed during exposure to $12.5 \mathrm{meq} \mathrm{H}^{+}$diluted in $250 \mathrm{ml}$ saline and the calculated $t_{1 / 2}$ of $\mathrm{H}^{+}$in the stomach.

cordable levels due to the generation of $\mathrm{CO}_{2}$ (Fig. 4). The $p \mathrm{CO}_{2}$ in luminal fluid measured thereafter fell with the passage of time. By extrapolation from the regression equations, the $p \mathrm{CO}_{2}$ present in the lumen immediately after the introduction of 12.5 meq $\mathrm{HCl}$ and 12.5 meq $\mathrm{NaHCO}_{3}$ was 1184 $\pm 139 \mathrm{~mm} \mathrm{Hg}$. The $t_{1 / 2}$ of the $p \mathrm{CO}_{2}$ was $18.5 \pm 0.7 \mathrm{~min}$ (Table 2).

The volume of fluid introduced into the stomach at the beginning of each test period $(250 \mathrm{ml})$ fell by $70 \pm 10 \mathrm{ml}$ during the $4-\mathrm{hr}$ experiments. The total amount of $\mathrm{CO}_{2}$ $\left(T \mathrm{CO}_{2}\right)$ calculated from the $\mathrm{pH}$ and $p \mathrm{CO}_{2}$ and from the calculated volume present in the stomach when each sample was taken,

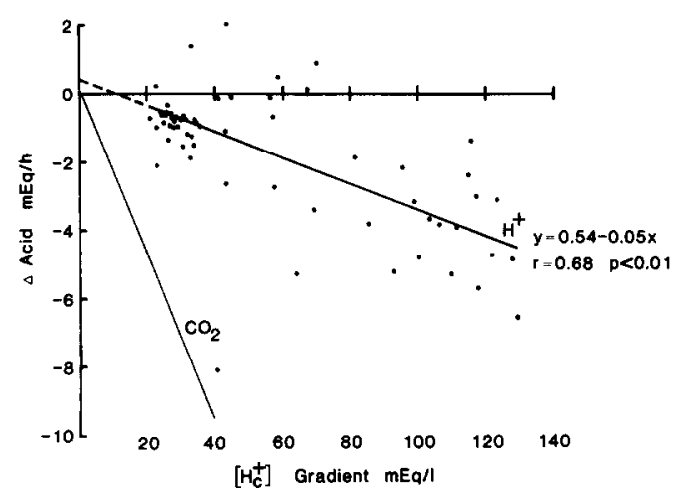

Fig. 7. Measured rate of $\mathrm{H}^{+}$loss from luminal fluid $\left(\Delta \mathrm{H}^{+}\right)$in each 20 -min period in each of seven dogs compared with the average $\left[\mathrm{H}_{\mathrm{c}}^{+}\right]$gradient between luminal fluid and arterial blood present at the beginning and the end of each 20-min test period. Comparison with $\mathrm{CO}_{2}$ loss at different $p \mathrm{CO}_{2}$ gradients (see Fig. 8). fell with the passage of time. The $t_{1 / 2}$ of the $T \mathrm{CO}_{2}$ was $32 \pm 4 \mathrm{~min}$ (Table 3). This $t_{1 / 2}$ was 5.1 times shorter than the $t_{1 / 2}$ of an equimolar amount of $\mathrm{HCl}(2 \mathrm{hr} 42 \mathrm{~min}$ $\pm 40 \mathrm{~min}$ ) administered in the preceding experiments. This difference was statistically significant $(t=3.94, P<0.001)$.

The rate at which $\mathrm{CO}_{2}$ left the stomach during each 20-min test period after the first hour's exposure to $\mathrm{HCl}$ and $\mathrm{NaHCO}_{3}$ was linearly related to the average $p \mathrm{CO}_{2}$ gradient present between the lumen and blood at the beginning and end of each 20 -min test period (Figs. 7 and 8 ). The positive intercept of this regression equation $(0.03 \mathrm{meq} / \mathrm{hr})$ was a reflection of the basal rate of acid se-

TABLE 2

$p \mathrm{CO}_{2}$ LOG REgRESSION EQUATION ${ }^{a}$

\begin{tabular}{lccc}
\hline \multicolumn{1}{c}{$r$} & $a$ & $b$ & $t_{1 / 2}$ \\
\hline & & & \\
0.97 & 1203 & -203.3 & 19.3 \\
0.99 & 1020 & -177.3 & 17.8 \\
0.99 & 1585 & -276.3 & 17.6 \\
0.997 & 1347 & -238.3 & 16.9 \\
0.98 & 769 & -126.7 & 20.8 \\
$\bar{x} \pm$ SEM & $1185 \pm 139$ & & $18.5 \pm 0.7$ \\
\hline
\end{tabular}

${ }^{a} \mathrm{pCO}_{2} \log$ regression equation occurring during exposure to $12.5 \mathrm{meq} \mathrm{HCl}$ and $12.5 \mathrm{meq} \mathrm{NaHCO}_{3}$ diluted in $250 \mathrm{ml}$ of saline and the calculated $t_{1 / 2}$ for the $p \mathrm{CO}_{2}$ in the stomach. 
cretion, and of the same order as that observed in the first hour of each experiment in these five dogs $(0.05 \pm 0.2 \mathrm{meq} / \mathrm{hr})$ and as that observed in the seven dogs exposed to $\mathrm{HCl}$ alone $(0.01 \pm 0.8 \mathrm{meq} / \mathrm{hr})$. The slope of this regression equation $(0.24)$ provided a measure of the gastric mucosal permeability to $\mathrm{CO}_{2}$ in the five dogs studied. The permeability to $\mathrm{CO}_{2}$ was 5.0 times greater than that to $\mathrm{H}^{+}$alone $(0.048)$. This difference between the slopes was statistically significant $(P<0.05)$.

\section{Intramural $p H$}

The back-diffusion of $\mathrm{H}^{+}$occurring following the addition of $12.5 \mathrm{meq}$ and also of $35 \mathrm{meq} \mathrm{HCl}$ to the stomach did not reduce the intramural $\mathrm{pH}$ significantly below control values (Fig. 6). The back-diffusion of $\mathrm{CO}_{2}$ occurring following the addition of 12.5 meq of $\mathrm{HCl}$ and 12.5 meq of $\mathrm{NaHCO}_{3}$ with the generation of $\mathrm{CO}_{2}$ did reduce the intramural $\mathrm{pH}$ below control values and below those observed with $\mathrm{HCl}$ alone. The intramural $\mathrm{pH}$ returned toward control values as the experiments progressed.

\section{5. $p \mathrm{CO}_{2}$ in Stomach vs $\mathrm{CO}_{2}$ in Duodenum}

The $p \mathrm{CO}_{2}$ in gastric and duodenal fluid rose in parallel during the first hour toward that observed in arterial blood (Fig. 5). The

\section{TABLE 3}

$\mathrm{TCO}_{2}$ LOG REgRESSION EQUATION $^{a}$

\begin{tabular}{lrcc}
\hline \multicolumn{1}{c}{$r$} & $a$ & $b$ & $t_{1 / 2}(\mathrm{~min})$ \\
\hline 0.95 & 15.9 & -2.36 & 29.5 \\
0.97 & 13.4 & -1.79 & 43.0 \\
0.996 & 23.1 & -3.67 & 23.5 \\
0.72 & 3.6 & -0.49 & 39.8 \\
0.98 & 11.9 & -1.89 & 23.3 \\
$\bar{x} \pm$ SEM & $13.6 \pm 3.2$ & & $31.8 \pm 4.1$ \\
\hline
\end{tabular}

${ }^{a} \mathrm{TCO}_{2}$ log regression equation occurring during exposure to $12.5 \mathrm{meq} \mathrm{HCl}$ and $12.5 \mathrm{meq} \mathrm{NaHCO}_{3}$ diluted in $250 \mathrm{ml}$ of saline and the calculated $t_{1 / 2}$ of the $\mathrm{TCO}_{2}$ in the stomach.

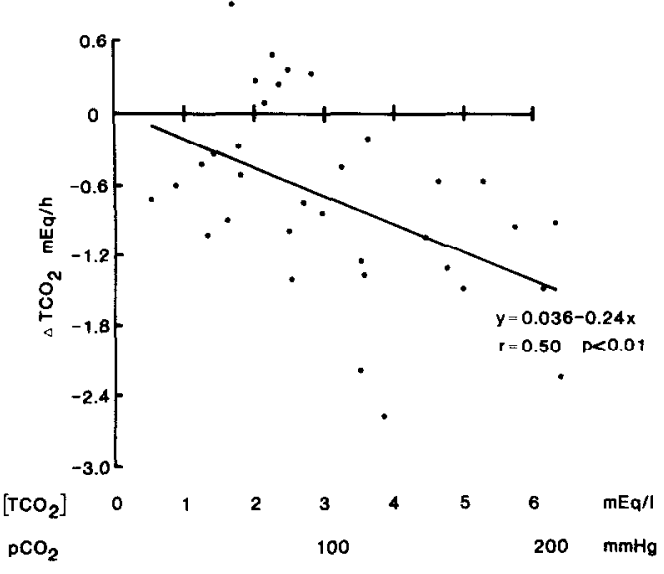

FIG. 8. Measured rate of $\mathrm{CO}_{2}$ loss by back-diffusion $\left(\Delta T \mathrm{CO}_{2}\right)$ during each 20 -min test period in five dogs compared with the average $\mathrm{CO}_{2}$ gradient measured at the beginning and end of each 20 -min test period and expressed in both $\mathrm{mm} \mathrm{Hg}$ and meq/liter.

$p \mathrm{CO}_{2}$ in the stomach and duodenum rose further in parallel and then returned toward basal values as the dogs were made to rebreathe and then allowed to breathe spontaneously again. The $p \mathrm{CO}_{2}$ in the stomach measured at each moment in the experiment was linearly related to that measured in the duodenum $(r=0.77, P<0.001)$ the slope of the regression equation being 0.8 .

\section{DISCUSSION}

This study has confirmed that both $\mathrm{H}^{+}$ [6] and $\mathrm{CO}_{2}$ [17] can diffuse from the lumen of the stomach. It has also shown in dogs that the stomach is 5.0 times more permeable to $\mathrm{CO}_{2}$ than to $\mathrm{H}^{+}$and that $\mathrm{CO}_{2}$ diffuses 5.1 times more rapidly from the stomach than an equimolar amount of $\mathrm{H}^{+}$. Gastric mucosa appeared also to be as permeable to $\mathrm{CO}_{2}$ as duodenal mucosa. In contrast to the relatively slow back-diffusion of $\mathrm{H}^{+}$, which was not accompanied by any appreciable increase in the $\mathrm{pH}$ of gastric luminal fluid or by any appreciable fall in intramural $\mathrm{pH}$ below control values, the more rapid back-diffusion of $\mathrm{CO}_{2}$ was accompanied by the neutralization of gastric luminal fluid and by a fall in intramural $\mathrm{pH}$ below 
control values and below that encountered with the exposure to $\mathrm{H}^{+}$alone. The findings are consistent with the hypothesis that the neutralization of acid by bicarbonate in the stomach increases gastric mucosal permeability to acid by transforming acid present in a relatively impermeable form $\left(\mathrm{H}^{+}\right)$ to acid present in a more permeable form $\left(\mathrm{CO}_{2}\right)$.

As in other studies the rate at which $\mathrm{H}^{+}$ diffused from the stomach was linearly related to the $\left[\mathrm{H}^{+}\right]$gradient across the stomach [14]. It was, by extrapolation from the regression equation in Fig. $7,7.1 \mathrm{meq} / \mathrm{hr}$ when applied in a concentration of $160 \mathrm{meq} /$ liter. This rate of $\mathrm{H}^{+}$back-diffusion compares favorably with the rates observed in healthy dogs [27] and human subjects [11, 25] during exposure to $160 \mathrm{meq} /$ liter of $\mathrm{HCl}$ alone. The basal rate of acid secretion observed in our experiments was very low and, in the control experiments, remained constant for the duration of each 4-hr experiment. The basal rate of acid secretion was too small to have caused any significant underestimation in the rate of $\mathrm{H}^{+}$back-diffusion.

The $p \mathrm{CO}_{2}$ in luminal fluid rose to an estimated $1185 \pm 139 \mathrm{~mm} \mathrm{Hg}$ immediately following the introduction of $12.5 \mathrm{meq}$ of $\mathrm{HCl}$ and $12.5 \mathrm{meq}$ of $\mathrm{NaHCO}_{3}$ into the stomach. This level approaches that calculated with the Henderson-Hasselbach equation to have been achieved following the generation $12.5 \mathrm{meq}$ of $\mathrm{CO}_{2}$ in $250 \mathrm{ml}$ of fluid at low $\mathrm{pH}(1629 \mathrm{~mm} \mathrm{Hg})$. A $\mathrm{pCO}_{2}$ approaching $1000 \mathrm{~mm} \mathrm{Hg}$ has been found by direct measurement in luminal fluid in dogs [24] and in man $[16,25,29]$. The $p \mathrm{CO}_{2}$ in luminal fluid fell rapidly from this high level with the diffusion of $\mathrm{CO}_{2}$ from the stomach and the formation of bicarbonate in luminal fluid. As in other studies the rate of $\mathrm{CO}_{2}$ diffusion was linearly related to the $p \mathrm{CO}_{2}$ gradient present $[15,30]$. It was, by extrapolation from the regression equation in Fig. $8,12.5 \mathrm{meq} /$ liter at the estimated $p \mathrm{CO}_{2}$ gradient present immediately following the addition of $\mathrm{HCl}$ and $\mathrm{HCO}_{3}$ to the stomach.
This rate of back-diffusion was 5.0 times greater than that $(2.5 \mathrm{meq} / \mathrm{hr})$ at the estimated $\left[\mathrm{H}_{\mathrm{c}}^{+}\right]$gradient present immediately following the introduction of $12.5 \mathrm{meq} \mathrm{HCl}$ into the stomach. It was twice as great as the rate of $\mathrm{H}^{+}$back-diffusion, calculated by extrapolation from the regression equation in Fig. 7, to occur during exposure to 160 meq/liter of $\mathrm{HCl}(7.1 \mathrm{meq} / \mathrm{hr})$, and approximately of the same order as that expected from the addition of bile to $160 \mathrm{meq} /$ liter of $\mathrm{HCl}$-an agent known to increase the mucosal permeability to $\mathrm{H}^{+}$and to cause acute gastric mucosal injury $[7,9,11,22]$. The back-diffusion of $\mathrm{CO}_{2}$ that occurred following the buffering of acid by exogenous bicarbonate was also accompanied by the neutralization of luminal fluid and by a transient fall in the intramural $\mathrm{pH}$ to values shown in other studies to be associated with the development of acute gastric mucosal injury [13]. The fall in intramural $\mathrm{pH}$ occurring with the back-diffusion of $\mathrm{CO}_{2}$ was presumably facilitated by the abundance of carbonic anhydrase in gastric mucosa [5].

The method of measuring intramural $\mathrm{pH}$ by hollow viscus tonometry depends in part upon the assumption that the $\mathrm{pCO}_{2}$ in the lumen of the stomach equilibrates with that in the wall of the stomach, and in part upon the knowledge that the $\mathrm{pCO}_{2}$ within the cellular cytosol is linearly related to the $p \mathrm{CO}_{2}$ in the extracellular environment [23]. This method was validated by direct measurement in preliminary experiments incorporating 114 paired measurements in 16 dogs. The validity of measuring intraluminal $\mathrm{pH}$ by hollow viscus tonometry was, however, established for lower $p \mathrm{CO}_{2}$ gradients than those encountered following the intragastric instillation of $\mathrm{HCl}$ and $\mathrm{NaHCO}_{3}$. As a $p \mathrm{CO}_{2}$ gradient exists between the superficial and deep layers of gastric mucosa, the magnitude of which is proportional to the $p \mathrm{CO}_{2}$ gradient between the lumen and blood, only the $p \mathrm{CO}_{2}$ in the superficial layers can justifiably be regarded as being accurately reflected by the $p \mathrm{CO}_{2}$ in the lumen of the stomach [4]. Thus, the measurement of intramural $\mathrm{pH}$ by 
hollow viscus tonometry, especially during the back-diffusion of $\mathrm{CO}_{2}$ in our studies, was a more accurate reflection of the $\mathrm{pH}$ in the superficial layers than the deeper layers of stomach. The measurement of $\mathrm{pH}$ by hollow viscus tonometry depends also upon the assumption that the bicarbonate concentration in the wall in the stomach is the same as that being delivered to the stomach in arterial blood. It is conceivable, therefore, that the measurement of $\mathrm{pH}$ by hollow viscus tonometry may have been artifactually low during the generation of an alkaline tide by the secretion of acid [14]. Fortunately, the basal rate of acid secretion, and hence the generation of an alkaline tide, was negligible in our studies. It is also conceivable that the measurement of intramural $\mathrm{pH}$ by hollow viscus tonometry may have been artifactually high during the back-diffusion of $\mathrm{H}^{+}$. The measurement of $\mathrm{pH}$ by hollow viscus tonometry was, however, validated under circumstances including those in which exogenous acid had been placed into the stomach in the concentrations used in these experiments. Thus the measurement of intramural $\mathrm{pH}$ by hollow viscus tonometry is likely to have been an accurate reflection of the $\mathrm{pH}$ in the superficial layers of the stomach in the circumstances in which our experiments were conducted, especially in those samples collected after the $p \mathrm{CO}_{2}$ in luminal fluid had had more than an hour to equilibrate with the $p \mathrm{CO}_{2}$ in the mucosa.

The degree to which the appearance of endogenous bicarbonate in the stomach might increase the back-diffusion of acid, and hence influence the intermucosal $\mathrm{pH}$, can be calculated from the gastric mucosal permeability to $\mathrm{H}^{+}$and $\mathrm{CO}_{2}$ and the $\left[\mathrm{H}^{+}\right]$ and $p \mathrm{CO}_{2}$ gradients generated by the buffering of acid in the stomach. The permeability of gastric mucosa to $\mathrm{H}^{+}$and $\mathrm{CO}_{2}$ was determined from our experiments. The $\left[\mathrm{H}^{+}\right]$ gradient can be derived from the $\mathrm{pH}$ of gastric juice. The $p \mathrm{CO}_{2}$ gradient can be calculated for the concentration of bicarbonate appearing in the stomach, upon its volume in proportion to the volume of gastric acid

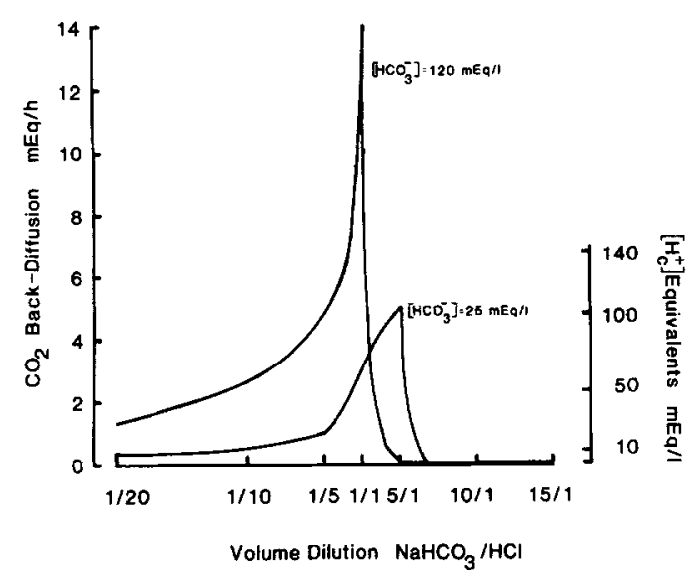

FIG. 9. Rate of acid back-diffusion calculated from Fig. 8 to occur as $\mathrm{CO}_{2}$ when $\mathrm{HCO}_{3}$, in concentrations of either 120 or $25 \mathrm{meq} /$ liter (the range found in endogenous secretions) is mixed in different proportions with $\mathrm{HCl}$ in a concentration of $140 \mathrm{meq} /$ liter. Comparison with rate of acid back-diffusion calculated from Fig. 7 to occur as $\mathrm{H}^{+}$with different concentrations of $\left[\mathrm{H}_{\mathrm{c}}^{+}\right]$.

present in the stomach, and upon the proportion of bicarbonate existing as $\mathrm{CO}_{2}$. The proportion of bicarbonate existing as $\mathrm{CO}_{2}$ depends upon the equilibrium $\mathrm{pH}$ of gastric juice, and may be calculated from the Henderson-Hasselbach equation. Thus, if the values $(0.048$ and 0.24$)$ derived from our experiments for the gastric mucosal permeability to $\mathrm{H}^{+}$and to $\mathrm{CO}_{2}$, respectively, are an accurate reflection of the values present in vivo when both the pylorus and esophago-gastric junction are open, and if the two component hypothesis for acid secretion is correct and acid is secreted in a constant concentration of $140 \mathrm{meq} / \mathrm{liter}$, the effects which the appearance of physiological amounts of endogenous bicarbonate in the stomach might have on back-diffusion of acid are as illustrated in Fig. 9.

Figure 9 shows that the appearance of only modest amounts of endogenous bicarbonate (in the stomach) may increase the rate of back-diffusion of acid many times above that occurring during exposure to $\mathrm{HCl}$ alone in those concentrations usually encountered in the stomach, especially at the interface between acidic and alkaline secre- 
tions where bicarbonate and acid are mixed in almost equal proportions. Direct measurements of $\mathrm{pCO}_{2}[24,29]$ and $\mathrm{pH}[20]$ in luminal fluid suggest that the interface between acidic and alkaline secretions, where the rate of back-diffusion is calculated to be greatest, is located in the duodenal bulb in healthy subjects and patients with duodenal ulcers, and in the stomach in patients with gastric ulcers [12]. If ulcers are indeed caused by the back-diffusion of acid and by a fall in the intramural $\mathrm{pH}$, as recent experiments would suggest [14], then the effect which bicarbonate has on the back-diffusion of acid at the interface between acidic and alkaline secretions may explain why ulcers occur in areas where "acidity alternates with neutrality" rather than in areas exposed to either acid or bicarbonate alone [20].

\section{REFERENCES}

1. Bergofsky, E. H. Determination of tissue $\mathrm{O}_{2}$ tensions by hollow visceral tonometers: effect of breathing enriched $\mathrm{O}_{2}$ mixtures. J. Clin. Invest. 43: 193, 1964.

2. Capper, W. M. Factors in the pathogenesis of gastric ulcer. J. R. Coll. Surg. Edinburgh 40: 21, 1967.

3. Code, C. F., Higgins, J. A., Moll, J. C., Orvis, A. L., and Scholer, J. J. The influence of acid on the gastric absorption of water, sodium, and potassium. J. Physiol. (London) 166: 110, 1963.

4. Comroe, J. H. Pulmonary gas diffusion. In J. Comroe (Ed.), Physiology of Respiration. Chicago: Year Book Med. Pub., 1974. Pp. 158-167.

5. Davenport, H. W. Gastric carbonic anhydrase. $J$. Physiol. (London) 97: 32, 1939.

6. Davenport, H. W. Gastric mucosal injury by fatty and acetylsalicylic acids. Gastroenterology 46: 245, 1964.

7. Davenport, H. W. Destruction of the gastric mucosal barrier by detergents and urea. Gastroenterology 54: 175, 1968.

8. DuPlessis, D. J. Pathogenesis of gastric ulceration. Lancet 1: 974, 1965.

9. Harmon, J. W., Doong, T., and Gadacz, T. R. Bile acids are not equally damaging to the gastric mucosa. Surgery 84: 79, 1978.

10. Hobsley, M., and Silen, W. Use of an inert marker (phenol red) to improve accuracy in gastric secretion studies. Gut 10: 787, 1969.

11. Ivey, K. J., DenBesten, L., and Clifton, J. A. Effect of bile salts on ionic movement across the human gastric mucosa. Gastroenterology 59: 683, 1970.

12. James, A. H., and Pickering, G. W. The role of gastric acidity in the pathogenesis of peptic ulcer. Clin. Sci. 8: 181, 1949.
13. Kivilaakso, E., Fromm, D., and Silen, W. Relationship between ulceration and intramural $\mathrm{pH}$ of gastric mucosa during hemorrhagic shock. Surgery 84: 70, 1978.

14. Kivilaakso, E., and Silen W. Pathogenesis of experimental gastric mucosal injury. N. Engl. J. Med. 301: 364, 1979.

15. Krogh, A. The rate of diffusion of gases through animal tissues, with some remarks on the coefficient of invasion. J. Physiol. (London) 52: 391, 1919.

16. McGee, L. C., and Hastings, A. B. The carbon dioxide tension and acid base balance of jejunal secretions in man. J. Biol. Chem. 142: 893, 1942.

17. McIver, M. A., Redfiels, A. C., and Benedict, E. B. Gaseous exchange between the blood and the lumen of the stomach and intestines. Amer. J. Physiol. 76: 92, 1926.

18. Moore, E. W., and Scarlatta, R. W. The determination of gastric acidity by the glass electrode. Gastroenterology 49: 178, 1965.

19. Penner, A., Hollander, F., and Saltzman, M. The gastric absorption of phenol red in humans. Amer. J. Dig. Dis. 5: 657, 1938.

20. Rhodes, J., and Prestwich, G. J. Acidity at different sites in the proximal duodenum of normal subjects and patients with duodenal ulcer. Gut 7: 509, 1966.

21. Rhodes, J., Barnardo, D. E., Phillips, S. F., Rovelstad, R. A., and Hoffman, A. F. Increased reflux of bile into the stomach in patients with gastric ulcer. Gastroenterology 57: 241, 1969.

22. Ritchie, W. P., Jr. Acute gastric mucosal damage induced by bile salts, acid, and ischemia. Gastroenterology 68: 699, 1975.

23. Roos, A., and Boron, W. F. Intracellular pH. Physiol. Rev. 61: 296, 1981.

24. Rune, S. J., and Henriksen, F. W. Carbon dioxide tensions in the proximal part of the canine gastrointestinal tract. Gastroenterology 56: 758, 1969.

25. Rune, S. J. Acid-base parameters of duodenal contents in man. Gastroenterology 62: 533, 1972.

26. Skillman, J. J., Gould, S. A., Chung, R. S. K., and Silen, $W$. The gastric mucosal barrier: Clinical and experimental studies in critically ill and normal man, and in the rabbit. Ann. Surg. 172: 564, 1970.

27. Steggerda, F. R., and Asher, D. R. Elimination of carbon ${ }^{14}$ bicarbonate following its introduction into the stomach of the rat. Fed. Proc. 15: 179 (abstract), 1956.

28. Werther, J. L., Janowitz, H. D., Dyck, W. P., Chapman, M. L., and Rudick, J. The effect of bile on electrolyte movement across canine gastric antral and fundic mucosa. Gastroenterology 59: 691, 1970.

29. Winship, D. H., and Robinson, J. E. Acid loss in the human duodenum. Gastroenterology 66: 181, 1974.

30. Wright, C. I. The diffusion of carbon dioxide in tissues. J. Gen. Physiol. 17: 657, 1934. 